question between 1937-38 by his ties to politically-compromised officials and his reluctance to engage in an indiscriminate purge of his organization. His fall in November 1938 was precipitated by a denunciation by O. P. Mishakova, a fanatical underling who questioned his vigilance as Komsomol boss. Bernstein also reveals that Kosarev was closely aligned with N. I. Ezhov-a fact that may have ensured him the latter's protection until late 1938, but thereafter left him painfully exposed. Ultimately, if Kosarev was the quintessential Stalinist Komsomol, he also epitomized the perils of this calling. ${ }^{7}$

Bernstein completes his story of the communist youth league by examining the degree to which the organization had become an instrument of party and state rule by 1941 . What had once been an autonomous organization with a militant following was now a bureaucratic apparatus tasked with supplying its membership with proper ideological, cultural, and paramilitary training. This ossification of the Komsomol's revolutionary élan is reflective of similar processes visible throughout the late interwar Soviet experiment.

DAVID BRANDENBERGER University of Richmond

\title{
The Wars of Yesterday: The Balkan Wars and the Emergence of Modern Military Conflict, 1912-13. Ed. Katrin Boeckh and Sabine Rutar. New York: Berghahn Books, 2018. 438 pp. Notes. Bibliography. Index. Tables. $\$ 140.00$, hard bound.
}

doi: 10.1017/slr.2018.300

Geographical and chronological marginalization have seriously hampered our understanding of the Balkan wars. The usual and now well-known prejudices against the supposed primitivism of southeastern Europe led many (although not all) contemporary western observers of the conflicts of 1912-13 to discount them as unimportant examples of modern warfare. And the proximity of the First World War, beginning while many of the Balkan armies were still mobilized, has regrettably (although understandably) led to an eclipsing of the conflicts, sometimes even in the combatant countries themselves. Attention, when it has fallen on this region, has not always been welcome. The conflicts of the 1990s led to some vulgarized grand comparisons that inevitably focused on violence of the societies in question. Perhaps the most notorious example of this was American diplomat and historian George F.

7. In attributing Kosarev's fate to his institutional ties, Bernstein discounts postStalin rumors that regarded his fall to be the result of a personal vendetta. According to materials assembled in 1954 that led to Kosarev's eventual rehabilitation, he had denounced L. P. Beriia while the latter was still secretary of the Transcaucasian party organization in the mid-1930s. When Beriia became NKVD chief in November 1938, he apparently took a personal interest in Kosarev's arrest and then ordered him to be beaten into confessing to counterrevolutionary crimes. See Rossiiskii gosudarstvennyi arkhiv sotsial'no-politicheskoi istorii (RGASPI), f. 17, op. 171, d. 439, 11. 134-140. Such a simplistic account likely underestimates the degree to which Kosarev was already thoroughly compromised by the time of Beriia's promotion. 
Kennan's old-new introduction to a 1993 reprint of the 1914 The Other Balkan War: Report of the International Commission on the Balkan Wars (Carnegie Endowment for International Peace, 1993).

This marginalization has, to a certain extent, been reproduced in the raft of publications and research that has accompanied the centennials of the Great War. Once again, coming to terms with the global conflict and its consequences has drawn attention away from these regional wars and away from the larger lessons we may take from them. The Balkan region, or at least Serbia, was placed at the heart of Christopher Clark's major new study of the origins of the First World War, albeit in a way that many felt reproduced the stereotypes of violence and atavism long at large in perspectives on the region. ${ }^{1}$ Robert Gerwarth's project on the protracted end of the First World War throughout the world found, incidentally, that not only did violence last well into the 1920s, but that in regions such as southeastern Europe it preceded the conventional starting point of $1914 .^{2}$ In this sense, the Balkan Wars were the first act of a cycle of violence in Europe that did not end until more than a decade later. Joshua Sanborn's landmark study of Russia and the First World War hints that global conflict was largely a war of decolonization, a war of people for and against empire rather than empires against one anothersimilar, in this sense, to the Balkan wars themselves. ${ }^{3}$

The editors of the volume under review, Katrin Boeckh and Sabine Rutar, have identified these and other existing shortcomings in the literature, and they have successfully moved beyond them. In so doing they have advanced our understanding of the Balkan wars, their conduct, the experience of the societies in question, and the longer-term implications of the conflicts. Their collection of essays is based on a conference held at Yildiz Technical University in Istanbul to mark the centennial of the outbreak of the first war. The editors' introduction sets out the research agenda (on which the contributors were briefed), that is, to apply the fields of "New Military History" where they have been lacking, to go "beyond the historical tropes that have long characterized the historiography of the Balkan Wars, the authors in this volume explore these wars in their sociopolitical and sociocultural contexts, placing societal, political and military actors at the center of attention" (5). The editors have assembled fifteen contributions, organized into four parts: an introduction; diplomatic and geographical aspects; armies, soldiers, and irregulars; and civilians, wounded, and invalids. The contributors themselves hail in large part from the countries in question: there are senior scholars reflecting on years of study as well as early career historians presenting evolving and original approaches to the field. The book showcases scholars whose work is not usually available in English or German, thus broadening the readership for their perspectives. And there is gender parity in each of the sections, which is not always the case in war studies, even in the "New Military History."

1. Christopher Clark, The Sleepwalkers: How Europe Went to War in 1914 (London, 2012).

2. Robert Gerwarth, The Vanquished: Why the First World War Failed to End, 1917-1923 (London, 2016).

3. Joshua A. Sanborn, Imperial Apocalypse: The Great War and the Destruction of the Russian Empire (Oxford, Eng., 2014). 
Each of the book's four parts contain useful and important insights. If the remit is breaking the boundaries imposed by traditional scholarship, Part IV, dealing with civilians, the wounded, and invalids, strikes out as the most original, broaching the still controversial and disputed matters of civilian casualties, societal mobilization, and war disability (this last a virtually untouched subject, still). Part II, dealing with diplomacy and geopolitics, isperhaps necessarily - the most conventional of the sections, but also features useful information on the asymmetrical perspectives of the bigger powers in the conflicts (Great Britain and France are absent, alas, and do not feature much at all throughout the volume). Part III, looking at combat experience and the important question of relations between regular armies and irregular forces is surely essential reading for any student of the conflicts. The topics are well-handled here, although there is still much work to be done. In the introduction, Wolfgang Höpken delivers a comprehensive and cogent essay on the conflicts and Balkan societies leading up to and during the wars, teasing out with considerable skill the relationship between Balkan "backwardness" and modernity. It would make an excellent addition to reading lists at all levels of teaching. Other standout chapters are Spyridon Tsoutsoumpis's study of Greek soldiers' wartime letters as a means of understanding the extent (or not) of popular mobilization, work reminiscent of Leonard Smith's research on French soldiers or the very best of "ego document" study from Germany; Mehmet Beşikçi piece on the mobilization of non-Muslims and non-Turks in the Ottoman army; Eyal Ginio's study of Ottoman Jewish philanthropic societies; the chapter of volume editor Sabine Rutar, which develops the fascinating category of "soldiers-to-be" in reference to men who saw in the Balkan conflicts a foreshadowing of their potential role in a future war; and Heike Karge's pioneering discussion of war neurosis and psychiatry in the aftermath of the wars, practically a brand new field which the author and a group of like-minded scholars is in the process of building from the ground up.

Höpken's overview chapter highlights a tension between the forces of modernization and "backwardness" in the Balkan region during the conflicts. The overall impression one takes from this volume is that the wars themselves were profoundly modern experiences: waged by modernized and mechanized armies, and done so for modern aims, to quote Höpken: "Highly modernized armies and an unprecedented mobilization of manpower came up against the limited institutional and organizational capacities of "premodern' states and societies" (46). Indeed they did, and it is difficult not to come away with the disquieting notion that the national armies of the Balkan states were modernizing institutions par excellence. How far, then, did the experience of military service and war forge national citizenship, turning peasants into Serbs, Greeks, and Bulgarians, as the Balkan states military and political elites hoped? The supreme successes of military mobilization in 1912 are suggestive, and many contemporary national elites claimed this general "war enthusiasm" was evidence of a unifying moment in Balkan societiesSpyridon Tsoutsoumpis's aforementioned chapter on Greek soldiers seems to show that the Greek "Megali Idea" had filtered through to the "common" soldier, but his examples are in most cases middle-class Greeks; the impact of war and nationalization of Serbian or Bulgarian peasants, for example, is 
not evident. National war enthusiasm has been analyzed and often debunked in western cases (most notably by Jeffrey Verhey's work on Germany). ${ }^{4}$ How well would these arguments transplant to southeastern Europe?

Some of the more controversial topics remain elusive, most importantly, I think, violence, especially as conducted against the Muslim population or by the notorious irregular and auxiliary paramilitary forces used to a greater or lesser degree by all the Balkan states (and by the Ottomans, too). The topic is dealt with even-handedly and untendentiously in this volume (by Alexey Timofeev, Natasha Kotlar-Trajkova, and Iakovos D. Michailidis), but we are still faced with the problem of using subjective sources to prove or disprove violent conduct: memoir literature, first-hand accounts, witness testimonies from the Carnegie commission, and reportage of "celebrity" observers such as Lev Trotskii. Fundamental questions are still open: were irregular auxiliaries of the Balkan armies more or less likely to commit violence? If, as intuition and study of similar groups in different theaters of conflict tell us, the latter is true, was this a result of indiscipline, or disciplined intention? Did it have the sanction and knowledge of regular armies? Ultimately, the iron and ineluctable laws of chronology foreclose many of the larger answers the Balkan wars might have delivered. To put it counterfactually: if the conflicts had not been followed immediately by the First World War we might have been able to better measure their impacts on modernization, creating a civic sense of nationhood amongst the pre-modern population, ironing out the longer-term territorial and political disputes between the Balkan states, or exacerbating them.

This is a well-curated and well-intended collection of essays. The editors and contributors have brought considerable knowledge and insight of the Balkan wars into the mainstreams of the New Military History. The collective linguistic and research scope of the contributors is comprehensive. Students and scholars of southeastern Europe will read these essays with profit, but it is the fields of European and global war studies that will benefit most from this excellent volume.

John PAUL NeWman Maynooth University, Ireland

\section{“Zakon" $i$ "grazhdanin" $v$ Rossii vtoroi poloviny XVIII veka: Ocherki isto- rii obshchestvennogo soznaniia. By Elena Marasinova. Historia Rossica. Moscow: Novoe literaturnoe obozrenie, 2017. 512 pp. Appendixes. Notes. Bibliography. Index. RUB 611, hard bound.}

doi: 10.1017/slr.2018.301

Could we see Russian society through the law? Not only the repressive apparatus of the state, its penitentiary mechanisms, and not only the ideology embodied in the rules of law, but also the real life that laws had to regulate? 